International Journal of

Health, Medicine and

Nursing Practice

(IJHMNP)

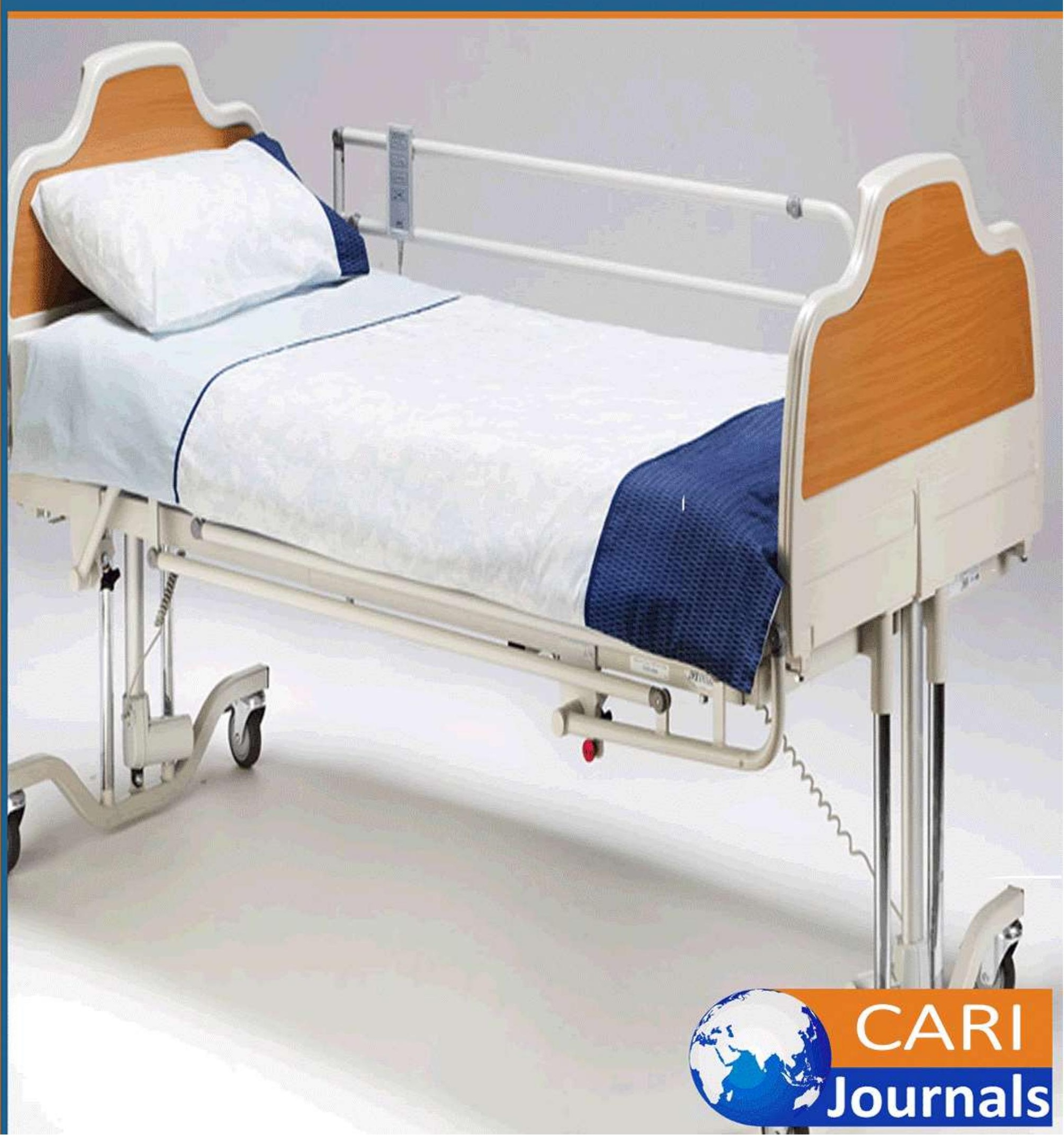




\title{
COVID-19 significant effect on global international economic relations
}

\author{
1*Tariro Portia Tendengu \\ Social Work Lecturer at the Zimbabwe Ezekiel Guti University \\ 2 Fadzai Mahere \\ Social Work student at the Zimbabwe Ezekiel Guti University Student
}

\begin{abstract}
The purpose of this paper is to reach the augment of COVID-19 effects on international economic relations. The globe has become a cohesive economic community with interdependence being fuelled by rising economies and the need to exchange technical knowhow, goods and services. Globalization has turned the world into one unit with diversified limbs that work in tandem with each other, for instance the lesser the lesser developed countries need raw material to sustain their industries. Now because of the unforeseen emergence of COVID-19 pandemic, social, political and economic modes of interaction have been obstructed normally to curb the spread of the virus which has claimed lives in the hundreds of thousands to millions. This in turn has hindered in some cases brought to a halt certain areas of the economy both internationally and nationally. Economic relations have been stunned by the introduction of COVID-19 measures like travel bans, limiting interactions between individuals and groups and limited time of operations for essential services. A desktop review analysis was used as the research methodology. Data collection methods that were used included observations, focus group discussions and interviews. The targeted population included international, statutory and non-statutory organizations in Zimbabwe. Findings from the study concluded that closure of borders during the COVID-19 pandemic affected imports and exports of trade, COVID-19 led to the loss of labour though massive deaths and quarantine measures and the effect of COVID-19 pandemic on oil dependent counties was severe.' Recommendations from the research affirm that governments and regional organisations should reunite in the global context so as to face pandemics, policy makers should implement effective policies which address economic relations between countries and countries should better prepare for such threats like COVID19 to economic relations and trade through enhancing technologies.
\end{abstract}

Key words: COVID-19, global, international economic relations

\section{Introduction}

COVID-19 is not only a global pandemic and public health crisis; it has also severely affected the global economy and financial markets. Significant reductions in income, a rise in unemployment, and disruptions in the transportation, service, and manufacturing industries are among the consequences of the disease mitigation measures that have been implemented in many countries. It has become clear that most governments are facing global financial transactions as a result of the virus. The COVID-19 pandemic season has caused direct impacts on income due to premature deaths, workplace absenteeism and reduction in productivity and has created a negative supply shock with manufacturing productive activity 
slowing down due to global supply chain disruptions and closure of factories. Upadhyay et al (2020) define COVID-19 as an infectious disease caused by a newly discovered corona virus. The Mirriam Webster dictionary defines COVID-19 as a mild to severe respiratory illness that is caused by a corona virus. It is transmitted chiefly by contact with infectious material or with objects or surfaces contaminated by the causative virus, and is characterised especially by fever, cough and shortness of breath and may progress to pneumonia and respiratory failure. COVID-19 is a disease caused by a respiratory virus first identified in Wuhan, Hubei Province, China in December 2019. Worldwide, COVID-19 has resulted in thousands of human infections, causing illness and in some cases death. Cases have spread to countries throughout the world, with more cases reported daily .The Maryland Department of Health (MDH, 2020).While international border closures have reduced air freight capacity, internal movement restrictions and closures have affected businesses, halted industrial production, and limited port activities. As a result, many countries find both their capacity to produce goods and to export them curtailed; this reduces the movement of products across borders. Production limitations are exacerbated by the inability to source necessary production inputs from abroad. Vidya and Prabheesh (2020) observed that as a result of COVID-19, there has been a considerable amount of reduction in the trade relations and volumes traded amongst the countries. They also noted that the pandemic had altered the trade network, and the trade pertaining to most of the economies had been adversely affected by the end of the year 2020 .

\section{The dependency theory}

The dependency approach, as propounded by philosophers such as Andre Frank Gunder of the 18th century can be criticised for not including the Human Rights Approach in development. The dependency theory attempts to explain the present underdevelopment state of many nations in the world by examining the patterns of interactions among nations and by arguing that inequality among nations is an intrinsic part of those interactions (UN, 2006). For instance, in relation to the tenants of the theory developing countries are to adopt western ideas in order to achieve development. On the same note, Irvine (2004) argued that the dependency theory is based on the assumption that the cause of the low levels of development in less economically developed countries (LEDC's) is caused by their reliance and dependence on more economically developed countries (MEDC's).Contrary to this scholarly view, it can be argued that in most cases less economically developed countries often fall trap as the dependency approach often lead to the so called, "dependency syndrome." The dependency theory as argued by Ghai (2007) forms its basic tenants based on , "a situation in which the economy of a certain group of countries is conditioned by the development and expansion of another economy to which their own is subjected."

\section{The effects of COVID-19 pandemic on international imports and export trade rates}

The World Trade Organization forecast a 12.9 percent drop in world merchandise trade in 2020, much of that decrease due to the COVID-19 crisis and national responses to it. The WTO has recently revised its forecast to a 9.2 percent decline in 2021 which is still severe compared to previous years. Zahonongo (2016) reveals that trade enables countries to experience economic growth and it brings in revenue through importing and exporting goods. Now that trade has been criticised due to the closure of borders one can see that COVID-19 has shacked the global trade and markets globally as growth in trade, goods and services declined. Economies are suffering as there is now loss of revenues and even informal traders are no longer able to cross borders thus affecting international economic relations. Bloom 
(2019) observed that, exports at the global level decreased by $2.5 \%$ in China which is considered to be the world's factory.

According to Blossom (2019) China suffered a decline in production across all sectors and goods, due to underutilisation of labour and capital. With higher trade costs, the price of a unit of imports and exports increased the competitiveness of Chinese production (Maliszewska, 2010).However it can be argued that, countries can prepare for threats such as COVID-19 through increasing gross domestic products. Pascual et.al (2020) define gross domestic product as the total monetary or market value of all finished goods and services produced within a country's borders in a specific period of time. By so doing even if borders close which affects trade the economy will not suffer as they would be relying more on local goods and local products. Since the goods would be found at an affordable price, it helps people not to suffer during the lockdown due to shortage of commodities. On that same note, Ivanov and Dolgui (2021) observed that companies should focus on scaling up production making sure supply chains are alive and reliable. By so doing companies will help the locals through availability of goods thus relying on local goods. In other parts of the world gross domestic production is increasing due to family or cottage level agricultural practices including other small-scale handicrafts productions in the society. This is reducing market demand as the locals are trying to maintain local traditional lifestyles rather than adapting to modernity. Therefore countries should increase gross domestic products to prepare for pandemic diseases such as COVID-19.

\section{The impact of COVID-19 on cross border international relations}

The COVID-19 Outbreak led the governments of many countries to impose restrictions on non-essential travel to countries affected by COVID-19, indefinitely suspending tourism travel, work visas and immigrant visas. Some countries placed a complete travel ban on all forms of inward or outward travel shutting down all airplanes flew almost empty due to mass passenger cancellations. Currently, most of the source countries have issued travel restrictions or are in total lockdown resulting in an increased number of booking cancellations. Tour operators and hotels in the resort city of Victoria Falls located in Zimbabwe. For instance had reported 80 percent cancellations by early March 2020 and more recently, most hotels have shut down altogether leading to loss of jobs and income In addition to the impact on productive economic activities, consumers typically changed their spending behaviour, mainly due to decreased income and household finances, as well as the fear and panic that accompany the epidemic. Service industries such as tourism, hospitality, and transportation have suffered significant losses due to reduction in travel. The International Air Transport Association projects) . According to the United Nations World Tourism Organization (UNWTO) latest estimate, there will be an expected fall of between 20-30\% that could translate into a decline in international tourism receipts (exports) of between US\$300-450 billion, almost one third of the US\$ 1.5 trillion generated in 2019. Taking into consideration the past market trends, it shows that between five and seven years' worth of growth would be lost because of Coronavirus. According to UN CTAD data a sudden decline in international trade was seen after the outbreak of the pandemic. In 2020, the global trade fallen by about $20 \%$ as compared to 2019 statistics. Likewise, according to the statistics of The Organisation for Economic Co-operation and Development (OECD) the crisis caused by COVID-19 led to $13 \%$ drop in global Gross Domestic Product. The outbreak of COVID-19 had badly affected the international trade while it is very necessary to save both livelihoods and lives of human being in the current globalised world. This epidemic had led to a huge interruption in international trade, affected badly both demands and supplies across the world. 
It had caused a sharp decline in the volume of exports of world's largest exporting countries like China and United States. The COVID-19 pandemic has drastically affected lives and livelihoods. In the process, it has also disrupted economic activities throughout the world. There are several dimensions to the pandemic that are likely to affect international trade Many productive activities have been disrupted, first in Asia and then in Europe, North America and the rest of the world, and there have been widespread border closures. This has resulted in a steep rise in unemployment, especially in the United States, with a consequent reduction in demand for goods and services. However, after the outbreak of coronavirus, the global FDI inflows has witnessed a sharp decline. As per the estimation by United Nations Conference on Trade and Development (UNCTAD), the COVID-19 outbreak could cause global FDI to shrink by 5\%-15\%, due to the downfall in manufacturing sector coupled with factory shutdown.

The possibility of contentment is to some extent, narrow for most of the countries around the globe, as they are going through the harrowing phenomenon of decelerating trade, deteriorating economic development, growing global imbalances, and devastating financial markets, therefore freezing their monetary systems, and their economies. It is a well-known fact that the Global Financial Crisis of 2008 happened to be a colossal shock to both the financial and the global trade markets. Just like that specific phenomenon, the current pandemic of the COVID-19 is also considered to have disrupted both the supply and demand functions of the affected economies. According to the projections made by (Annual Report, 2020), the COVID-19 pandemic has brought about several adverse effects with it. A Moreover, even the developed economies are anticipated to contract by 7 percent in the year 2020. However, the developing and the emerging economies are anticipated to shrink by 2.5 percent. In the same pattern, in the year 2020, global trade is projected to shrink by up to 13 percent. These estimates indicate that there is an expectation of a substantial deterioration in the global trade due the COVID-19 pandemic.

\section{COVID-19 and global economy recession}

The COVID-19 proved to alter the global economy in recession. It has affected all segments of economy mostly due to lockdown in majority countries of the world in response to support crude oil prices hit by the pandemic Coronavirus disease, major oil producers proposed to reduce production, as people consume less and decline in travel. The Oil exporters' group OPEC agreed to cut supply by 1.5 million barrels per day (bpd) until June and the plan was for non-OPEC states, including Russia, to follow the trend. However, this did not happen as Saudi Arabia on 08 March announced that it would increase production, which escalated oil wars as non-OPEC members retaliated, resulting in tumbling oil prices. The late 2014 drop in crude oil prices contributed to a significant decline in GDP growth for Sub-Saharan Africa from 5.1 percent in 2014 to 1.4 percent in 2016. During that episode, crude oil prices fell by $56 \%$ over seven months. The current decline in crude oil prices has been far more rapid with some analysts projecting even more severe price decline in 2014 (Brookings Institution, 2014). Already, crude oil prices have fallen by 54 percent in the last three months since the start of the year, with current prices falling below $\$ 30$ per barrel. Nonoil commodity prices have also declined since January, with natural gas and metal prices dropping by 30 percent and 4 percent, respectively (Brookings Institution, 2020).

\section{Methodology}

\section{Research Design}


The researcher used qualitative and quantitative research designs in examining the community response to the novel virus COVID 19 in the town of Marondera. Tashakkori and Teddlie (2008: 22) describe mixed-methodology as 'studies that are products of the pragmatist paradigm and that combine the qualitative and quantitative approaches within different phases of the research process.' Paradigm wars between qualitative and quantitative research approaches have resulted in mixed-method studies emerging to become a widely used mode of inquiry. Mixed methods studies stem from a pragmatic philosophical worldview that draws on employing 'what works,' using diverse approaches, giving primacy to the importance of the research problem and questions, and valuing both objective and subjective knowledge (Creswell et al, 2012: 4).

Qualitative research, broadly defined, means any kind of research that produces findings not arrived at by means of statistical procedures or other means of quantification (Strauss \& Corbin, 2008 ) and instead, the kind of research that produces findings arrived from realworld settings where the phenomenon of interest unfold naturally (Patton, 2001).Denzin and Lincoln (2000) claim that qualitative research involves an interpretive and naturalistic approach: "This means that qualitative researchers study things in their natural settings, attempting to make sense of, or to interpret, phenomena in terms of the meanings people bring to them"

According to Tolossa (2005:1), while quantitative data refers to measurable and countable demographic and economic characteristics of, for example, a household, qualitative data consists of a range of behavioural traits such as beliefs, customs, values, knowledge, and experiences, as well as various events, processes and resulting structures, which cannot be accounted for in numerical terms. The researcher gathered such data through in-depth interviews and focus group discussions with participants. Researcher also made use of observations to learn more about power relations between various actors, levels of interaction between participants of group discussions as well as the nuances that go with face to face interactions and responses to questions on sensitive issues. By scrutinizing household quantitative and qualitative data, the researcher was able to understand the impact of COVID 19 to the community, family and individuals. Tolossa (2005) concludes that if gathered on the basis of appropriate and relevant methods, qualitative and quantitative data will complement each other in such endeavors as studying social phenomena.

\section{Sample selection, Data collection procedure and Unit of analysis}

In line with the mixed triangulation approach of this study, both qualitative and quantitative sampling techniques were utilised for this research. Therefore, both probability and nonprobability sampling techniques were used. The researcher used purposive or judgmental sampling as non-probability techniques to select key informants. Purposive sampling is utilised when the researcher selects a sample from which most information can be learned (Merriam, 2009). Patton (2002) further argues that it is the most common sampling strategy in qualitative research as it targets cases rich in information about issues of central importance to the purpose of the research. Researcher purposively selected key informants from the Municipality, The Ministry of Health, The Ministry of Education. Following the survey, six participants for the in-depth interviews were purposively selected; two from each of the three clusters mentioned above.

In order to further enhance representativeness of the study, randomisation was also an important aspect of this research. Therefore, some probability sampling techniques was utilised. It was impractical for the researcher to obtain a comprehensive sampling frame of all 
respondents that comprise the target population in the area. For this type of problem, Rubin and Babbie (2011) recommend that cluster sampling be used. Bernard (2006) states that cluster sampling is based on the fact that people act out their lives in more or less natural groups, or clusters. The respondents and participants under consideration were clustered in geographic areas like high density surbubs and low density suburbs. From within such clusters, respondents were stratified according to their wards and further according to residential areas. Households from high and low density suburbs were randomly selected for study within each of the above clusters. Roughly ten respondents were chosen in each ward, to make a total of seventy that were covered by the survey.

\section{Data analysis, interpretation and bias reduction}

Data presentation and analysis involve organising data into specific criteria, reducing it to a more manageable form and displaying it in some form to aid analysis and interpretation Ellsberg and Heise (2005). According to Creswell $(2010 ; 190)$ states that data analysis in mixed methods research 'occurs both within the quantitative (descriptive and inferential numeric analysis) and the qualitative (description and thematic text or image analysis) approach and often between the two approaches.' Using the concurrent design, the researcher qualified quantitative data through the creation of factors or themes that were compared with themes from the qualitative database (Creswell, 2010). The researcher followed the presentation structure proposed by Onwuegbuzie and Teddlie' (2003) and Creswell (2010) for concurrent studies.

Onwuegbuzie and Teddlie (2003) propose a seven (7) stage model for the presentation and analysis of mixed data that was utilised by the researcher. The first stage involved data reduction, i.e. reducing the dimensionality of qualitative and quantitative data. This involved thematic analysis of qualitative data and factor analysis of quantitative data. Quantitative data are displayed in the form of tables and graphs, whilst qualitative data are displayed through themes. Data transformation involved converting quantitative data into narratives that can be analysed qualitatively. The data was then correlated through analysis of thematic areas and frequencies. In the next stage, the data was consolidated by combining both qualitative and quantitative data to create consolidated data sets. The data was then integrated into a coherent whole.

\section{Feasibility of the study}

According to Rubin and Babbie (2011:141), 'common issues determining the feasibility of a study are its scope, time it will require, costs, ethical considerations and the cooperation it will require from others.' The study was conducted in Marondera Residential area . Researcher recognises to the glitches surrounding the scope of the study, time and budgetary limitations that impacted on the study. The researcher thoroughly considered and mitigated all factors that could have rendered the research untenable.

\section{Recommendations}

The researcher recommends that:

$\checkmark \quad$ International organisations should provide funding for research on communicable disease.

$\checkmark \quad$ In school curriculum topics on hygiene, sanitation and communicable diseases should be included. 
In developing countries such as Zimbabwe, human capital development focus should be on courses in Public Health thus in Polytechnical colleges, technical colleges and universities.

$\checkmark \quad$ New laws and policies should be implemented by policy makers in matters pertaining to immigration for example a Health Clearance certificate should be a must.

$\checkmark \quad$ Governments should ensure that state officials receive training in disaster management and preparedness.

$\checkmark \quad$ Money should be allocated to small and medium enterprises plus the informal sector from the Global Fund.

$\checkmark \quad$ Nation states should ensure proper methods of strategic cash reserves are in place ( hedging against disasters).

$\checkmark \quad$ That nation states should allocate resources into research in medical herbs.

$\checkmark \quad$ Communities themselves need to be powerful forces in addressing issues related to disease prevention. This means communities must be their own advocates in their quest for security for example engaging in dialogues on strategies and measures that can be taken to curb the spread of diseases. Such measures could include forming cooperatives and organisations that negotiate for workshops and platforms ha address issues related to illness.

\section{Conclusion}

The COVID-19 pandemic has been so disruptive as witnessed by the negative it has had on global trade, markets and industries which affected international relations.

\section{References}

Annual Report 2020. (n.d.). Retrieved April 18, 2021, from https://www.worldbank.org /en/about/annual-report

Annual Report 2020. (n.d.). Retrieved April 18, 2021, from https://www.worldbank.org/en/about/annual-report

Bleamey, M.F (1996): Macroeconomic stability, investment and growth in developing countries. Available at https://www sciencedirect.com/science/article/abs/pii/0304387895000496

Bernard, R. H (2006). Research Methods in Anthropology (4 $4^{\text {th }}$ Ed) Qualitative and Quantitative. New York: Rowan and Littlefield Publisher

Creswell, J. W. (2012).Educational Research Planning, Conducting and Evaluating. Qualitative and Quantitative Research. Boston: Pearson Education.

Denzin, N and Lincoln S (2000.) The Sage Handbook of Qualitative Research

Ellsberg, M. and Heise, L. (2005). Researching Violence Against Women: A Practical Guide for Researchers and Activists. Geneva: World Health Organisation.

Food and Agriculture Organisation of the United Nations. Migrant workers and the COVID19 Pandemic. Rome (2020).

Kartik Jayaram, Acha Leke, Amandla Ooko-Ombaka, and Ying Sunny Sun (2020) Tackling COVID-19 in Africa: 
International Journal of Health, Medicine and Nursing Practice ISSN 2710-1150 (Online)

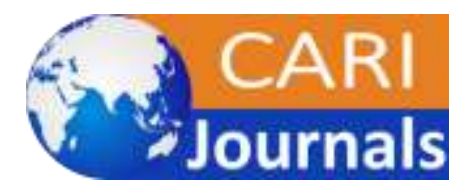

Vol.3, Issue No.4, pp $17-24,2021$ www.carijournals.org

Kartik Jayaram, Acha Leke, Amandla Ooko-Ombaka, and Ying Sunny Sun (2020) Tackling

COVID-19 in Africa: An unfolding unfolding health and economic crisis that demands bold action

Ghai (2001). Human Rights and Social Development: Towards Democratisation and Social Justice, United Nations Research Institute, London

Irvire, I . (2004), Conversational competence and social development, Cambridge, New York

Merriam, S.B. (2009). Qualitative Research: A Guide to Design and Implementation. London: John Wiley and Sons.

Onwuegbuzie, A.J. and Teddlie, C. (2003). 'A Framework for Analysing Data in Mixed Methods Research.' in Tashakkori, A. and Teddlie, C. (Eds.). Handbook of Mixed Method in Social and Behavioral Research pp. 351-383. Thousand Oaks, CA: Sage.

Patton, M. (2002). Qualitative Research and Evaluation. Thousand Oaks: Sage Publications Inc.

Rubin, A and Babbie, E 2011 Research Methods for Social Work. Belmont: Brooks

Strauss, A., \& Corbin, J. 1990. Basics of qualitative research: Grounded theory procedures. The Qualitative Report, 8(2), 12-18.

Tashakkori, A., and Teddlie, C. (2010). Handbook of Mixed Methods in Social and Behavioural Research. Thousand Oaks, CA: SAGE Publications, Inc.

Tolossa, D. (2005). 'Food Security Status of Peri-Urban Small-Scale Irrigation Project Beneficiary Female Headed Households in Kobo Town, Ethiopia.' Journal of Food Security. Science and Education Publishing.

United Nations (2006).,Survey of Economic and Social Developments in ESCWA Region, New York London.

Vidya, C. T., \& Prabheesh, K. P. (2020). Implications of COVID-19 pandemic on the global trade networks. Emerging Markets Finance and Trade, 56(10), 2408-2421.

https://doi.org/10.1080/1540496X.2020.1785426 